\title{
KEBANGKITAN HAK-HAK SIPIL PENGHAYAT KEPERCAYAAN PARMALIM PASCA PASAL 61 AYAT (1) PUTUSAN MAHKAMAH KONSTITUSI NOMOR 97/PUU-XIV/2016 DI KOTA MEDAN
}

\author{
Oleh: \\ Gomgom T. P Siregar ${ }^{1)}$ \\ Rudolf Silaban ${ }^{2)}$ \\ Peri Gustiranda ${ }^{3)}$ \\ Universitas Darma Agung, Medan ${ }^{1,2,3)}$ \\ E-mail: \\ gomgomsiregar@gmail.com ${ }^{11}$ \\ banglabanshmh@gmail.com $^{21}$ \\ peri@gmail.com $^{3)}$
}

\begin{abstract}
This study aims at finding the truth and the inclusion of words of believers in the electronic identity card, especially followers of Parmalim in the city of Medan even though the religious column on their electronic KTP is blank or a sign (-). The research method used in this study is normative juridical, which uses a library study on Population Administration Law to the 2016 Constitutional Court Number and Constitutional Court Decision Number 97 / PUU-XVI / 2016 in Medan City. The research result is that the civil rights of the trustees, namely the right to social security, have easy access to population documents such as electronic ID cards, family cards, marriage certificates and birth certificates for Parmalim in the city of Medan. May have access to work, can access rights to social security, can access population documents such as electronic ID cards, family cards, marriage certificates and birth certificates. Likewise, the applicant's children may apply for a job even though the religious column on the electronic KTP is marked with a strip or (-).
\end{abstract}

Keywords: Civil Rights, Beliefs of Trust, Parmalim

\section{ABSTRAK}

Penelitian ini bertujuan mencari kebenaran dan pencantuman kata penghayat kepercayaan pada KTP - elektronik khususnya penganut Parmalim di Kota Medan meskipun kolom agama pada KTP elektronik mereka kosong atau tanda -. Metode penelitian yang dipakai dalam penelitian ini adalah yuridis normative, yakni menggunakan studi kepustakan Undangundang Administrasi Kependudukan ke MK tahun 2016 Nomor dan Putusan Mahkamah Konstitusi Nomor 97/PUU-XVI/2016 di Kota Medan. Adapun hasil penelitian adalah bahwa Hak-hak sipil penghayat kepercayaan yakni hak atas jaminan sosial, sudah mudah mengakses dokumen kependudukan seperti KTP elektronik, KK, Akta Nikah dan Akte Kelahiran kaum Parmalim di kota Medan. Telah boleh mengakses pekerjaan, dapat mengakses hak atas jaminan sosial, dapat mengakses dokumen kependudukan seperti KTP elektronik, KK, Akta Nikah dan Akte Kelahiran. Demikian juga anak pemohon boleh melamar pekerjaan meskipun kolom agama di KTP elektronik bertanda strip.

\section{Kata Kunci : Hak-Hak Sipil, Penghayat Kepercayaan, Parmalim}

\section{PENDAHULUAN}

Keberadaan agama masyarakat yang bersifat lokal seharusnya memperoleh porsi pelayanan oleh pemerintah di bidang administrasi dan kependudukan yang diperoleh oleh umat beragama lain sesuai dengan amanat Undang-undang Nomor 23 Tahun 2006 tentang Administrasi Kependudukan yang memberikan kebebasan bagi setiap 
individu untuk menjalankan ajaran agam yang dianutnya.

Ada beberapa organisasi penghayat kepercayaan terhadap Tuhan Yang Maha Esa berdasarkan penelitian Tahun 2017 di Indonesia yaitu:

1. Sumatera Utara; Balai Pustaka Adat Marga Silima (PAMENA); Golongan Siraja Batak; Persatuan Ugamo Parmalim Adat Budaya Beringin Indonesia (PAMBIPABBI); Purwo Madio Wasono; Ugamo Malim (PARMALIM); Galih Puji Rahayu; Ilmu Roso Sejati; Rumah Sipitu Ruang; Persatuan Warga Rahayu Slamet (PWRS); Ugamo Bangso Batak ( UBB); Organisasi SIRAJA BATAK.

2. Riau terdiri dari Batin Suku Akit.

3. Lampung terdiri dari : Ilmu Goib; Bumi Hantoro; Pendidikan Kerohanian Luhur (PKL).

4. Banten terdiri dari Gayuh Urip Utami.

5. DKI Jakarta terdiri dari himpunan Amanat Rakyat Indonesia; Paguyuban Sumarah; Sadar Langsung; Sari Budaya; Paguyuban Ngesti Budoyo.

6. Jawa Barat terdiri dari Buhdi Rahayu, Aliran Kepercayaan Aji DIpa.

7. Jawa tengah terdiri dari Kejaten, Paguyuban Pangudi Kaeruh aKerohnian Panunggalan, Pangudi Rahayuning Bawona, Parseban Jati, Perguruan Tri Jaya, Tunggul Sabda Jati, Paguyuban Kejiwaan, Sukmo Sejati, Kawruh Hak, PAKARTI, Pangudian Tri Tunggal Bayu.

Paham keagamaan parmalim bersifat lokal dan hingga kini masih ada.Ajaran dan ritual keagamaan parmalim masih dipatuhi dan ditaati sehingga pemerintah perlu melakukan pembinaan dan pelayanan terhadap komunitas agama parmalim itu. Agama - agama leluhur tidah hanya bicara tentang hubungan antara manusia dengan Tuhan tetapi hubungan manusia dengan alam sekitarnya.

Sebelum reformasi, banyak hambatan terhadap penganut agama yang pindah ke dalam agama seperti Islam, Katolok dan Kristen. Seperti di Jawa, mereka menamakan dirinya dengan AKUR yang merupakan singkatan dari Adat Karihun Urang yang artinya Adat Leluhur Kami yaitu adat Leluhur orang Sunda. AKUR juga dalam bahasa Indonesia berarti rukun dan harmonis. Dalam ajaran AKUR, menciptakan masyarakat yang rukun dan harmonis sepengertian bukan sepengakuan.

Sepengertian artinya kepercayaan terhadap Tuhan yang Maha Esa sama. Agama atau kepercayaan apapun tujuannya sama menyembah kepada Tuhan dan mencari keridoannya Dia yang menentukan baik dan buruknya sesuatu. Kata sepengakuan berarti satu agama atau satu adat. Kalau sepengakuan yang dikembangkan akan menimbulkan konflik dalam masyarakat sebab orang berusaha agar pihak lain untuk ikut dalam agama yang dianutnya.

Di Kota Medan, Parmalim merupakan agama local. Sebutan untuk penganut Agama Malim berlokasi di Jalan Air Bersih Ujung Kelurahan Binjai Kecamatan Medan Denai, Kota Medan. Rumah suci Parmalim ini bernama Bale Parsantian Ginomongan Ni Bale Pasogit Partonggoan.Jajaran pemerintah daerah sudah mengakomodir segala kebutuhan mereka, tanpa diskriminasi. Hak administrasi kependudukan sangat diperhatikan. Ugamo Malim diartikan sebagai Agama Suci oleh bangsa Batak terdahulu, malim tidak disebarluaskan melalui misionaris misionaris seperti agama-agama lainnya. Itulah mengapa penghayat aliran kepercayaan ini tak begitu berkembang di Indonesia. Parmalim di Indonesia saat ini jumlahnya mencapai 1.300 Kepala Keluarga (KK).Jika diuraikan, penganutnya mencapai 9.000 orang sesuai data yang dimiliki Pengurus Parmalim. 


\section{TINJAUAN PUSTAKA}

Parmalim menyembah Mula Jadi Nabolon yang artinya Tuhan Yang Maha Besar.Berdasarkan sejarahnya, umat Parmalim berawal dari amanah Dinasti Sisingamaraja yang terbunuh pada saat perang melawan penjajah Belanda.Sisingamaraja memerintah untuk menidirikan Bale Pasogit untuk menghimpun orang-orang yang setia dengan keyakinan terhadap Mulajadi Nabolon di Kantor Demang di Balige tahun 1913.Kemudian Pemerintah belanda mengadakan penyelidikan atas kegiatan penyebaran ajaran ugamo Malim di Hutatinggi Laguboti melalui Surat Contoleur van Toba Nomor 1494/13 tangga; 25 Juni 1921.

$$
\text { Ajaran Parmalim melakukan }
$$
peribadatan rutin setiap Sabtu sebagai rasa syukur, pemujaan dan memuliakan Mulajadi Nabolon sang pencipta langit dan bumi. Selain Mararisabtu parmalim juga melakukan peribadatan Pameleon Bolon sebagai ibadah ritual syukuran kehidupan yang dilaksanakan pada bulan ke -lima, ritual pengampuan dosa Mangan Napaet pada bulan ke 12 dan mensyukuri lahirnya utuan Tuhan kepada manusia yang dirayakan hari kedua dan ketiga bulan kesatu sesuai kalender Batak .

Kepemimpinan (Pinisepuh) adalah :

1. Raja Si Singamaraha sebagai Malim dan Imam bagi Orang Batak. Raja Nasiakbagi menunjuk dan mengamanahkan kepada muridnya

2. Raja Mulia Naipospos untuk memimpin pengikutnya dan menyebarkan Ugamo Malim disebut Ihutan Bolon Par Malim disebut juga Induk Bolon dan generasi I Pemimpin Parmalim.

3. Raja Ungkap Naipospos, putera tunggal Raja Mulia Naipospos pada generasi II tahun 1956. Beliau menulis ajaran-ajaran tertulis yang menyebarkan kepada seluruh Parmalim. Dan terdaftar pada inventaris Penghayat Kepercayaan terhadap tuhan yang maha esa yang dilaksanakan pemerintah (Depdikbud) pada tahun 1980 yaitu Nomor I/136/F3/N.1.1/1980.

4. Raja Manangkok Naipospos, sebagai Ihutan Parmalim generasi ketiga. Beliau membukukan ajaran dan bimbingan terulis yang pernah dibuat Raja Ungkap kemudian disebar luaskan kekalangan parmalim yang jumlahnya semakin banyak.

5. Raja Monang Naipospos, generasi keempat. Beliau aktif dalam upaya -upaya pemberdayaan dan pembahruan Parmalim dan menguatkan nilai-nilai Hamalimon dalam praktik kehidupan nyata sesuai kredo Parmalim naimbaru mulak tu hapitaton hasintaingan hamalimon.

Tinjauan Tentang Hak-hak Sipil Penghayat Kepercayaan, Pasal 28 D ayat 1 UUD 1945 menegaskan adanya jaminan kepastian hukum dan perlakuan yang sama di hadapan hukum bagi setiap warga Negara dalam ruang Negara hukum. Didalam KTP terdapat kolom penghayat kepercayaan atau kepercayaan terhadap Tuhan Yang Maha Esa alasnnya penghayat kepercayaan ditafsirkan sebagai pelakunya bukan keyakinan yang dianutnya.

Hak-hak sipil penghayat kepercayaan yakni hak atas jaminan sosial, kesulitan mengakses dokumen kependudukan seperti KTP elektronik, KK, Akta Nikah dan Akte Kelahiran.

Tinjauan tentang Ketentuan Pasal 61 ayat (1) dan ayat (2) juncto Pasal 64 ayat (1) dan ayat (5) UU Administrasi Kependudukan .

Pasal 64 ayat (1) dan ayat (5) UU Administrasi Kependudukan menyatakan bahwa keterangan tentang agama dalam Kartu Tanda Penduduk (KTP) Elektronik bagi penduduk yang agamanya belum diakui sebagai agama berdasarkan ketentuan peraturan perundang-undangan atau bagi penghayat kepercayaan tidak 
diisi, tetapi tetap dilayani dan dicatat dalam data base kependudukan.

Kedua pasal ini menghilangkan hak warga Negara untuk mendapatkan Kartu Keluarga (KK) dan Kartu Tanda Penduduk (KTP) elektronik meskipun dalam pasal undang-undang a quo disebutkan tetap dilayani dan dicatat dalam data base kependudukan. Frase tetap dilayani dan dicatat dalam data base kependudukan pada dasarnya inkontitusional sebab dengan pasal undang-undang a quo mengakibatkan beberapa hal, yaitu:

1. Penghayat kepercayaan dan pemohon sulit mendapatkan KK dan KTP Elektronik;

2. Meskipun aparatur pemerintahan melayani dengan memberikan $\mathrm{KK}$ dan KTP dengan kolom agama kosong atau di strip bagi penghayat kepercayan dan menimbulkan masalah karena tidak diterima di tempat pekerjaan karena kolom agamanya kosong atau tanda strip/dan masalah lainnya.

Telah boleh mengakses pekerjaan, dapat mengakses hak atas jaminan sosial, dapat mengakses dokumen kependudukan seperti KTP elektronik, KK, Akta Nikah dan Akte Kelahiran. Demikian juga anak pemohon boleh melamar pekerjaan meskipun kolom agama di KTP elektronik bertanda strip.

Hak asasi penghayat kepercayaan dan pemohon selaku warga Negara seharusnya dilindungi, dihormati dan dipenuhi Negara.Padahal keberadaan pasal undang-undang a quo berpotensi menghilangkan dan mengingkari Hak Asasi Penghay Kepercayaan dan Pemohon.Komunitas penghayat kepercayaan yaitu mendapatkan dokumen kependudukan sebagaimana dimaksud dalam Pasal 2 huruf a UU Administrasi kependudukan yang menyatakan bahwa setiap penduduk mempunyai hak untuk memperoleh Dokumen Kependudukan.

Pasal 61 dan pasal 64 yang berada di bawah sub bab Dokumen Kependudukan dimana dokumen kependudukan merupakan dokumen yang mempunyai kekuatan hukum sebagai alat bukti autentik yang mencakup pengaturan atas sejumlah hak kebebasan beragama dan berkeyakinan. Untuk tertib adminstrasi kependudukan sama sekali tidak boleh mengurangi hak-hak warga Negara dimaksud termasuk ha katas kebebasan beragaman dan berkeyakinan. Karena tidak ada warga Negara yang terdata data base kependudukan yang elemen data kependudukan di dalamnya tidak diisi dan secara tidak sesuai dengan agama dan keyakinan yang dianutnya.

Agama dalam Pasal 61 ayat 1 hanya akan ditemukan apabila konteks ayat 2 harus dipahami. Ada tiga asas dalam penafsiran kontekstual, yaitu: pertama, asas Noscitur a sociis, yang mengandung pengertian bahwa suatu kata atau istilah harus dikaitkan dengan rangkaiannya; kedua, asas ejusdem generis, yang mengandung pengertian bahwa makna suatu kata atau istilah dibatasi secara khusus dalam kelompoknya; dan ketiga, asas expressio unius exclusio alterius yang mengandung pengertian bahwa jika suatu konsep digunakan untuk satu hal maka ia tidak berlaku untuk hal lain.

Maksud asas Noscitur a sociis kata agama dalam Pasal 61 ayat 1 dan pasal 64 ayat 5 dimaksudkan sebagai agama dalam pengertian yang diakui sebagai agama sesuai dengan ketentuan Peraturan Perundang-undangan yang berarti tidak termasuk kepercayaan terhadap Tuhan Yang Maha Esa. Sesuai dengan asas ejusdem generis telah ternyata pula bahwa kata atau istilah "agama" dalam Pasal 61 ayat (1) dan dalam Pasal 64 ayat (1) maupun istilah "agama" dalam Pasal 61 ayat (2) dan dalam Pasal 64 ayat (5) UUAdministrasi Kependudukan oleh pembentuk undang- undang memang digunakan semata-mata bagi pengertian agama "yang diakui sebagai agama sesuai dengan ketentuan Peraturan Perundangundangan",sehingga tidak dapat digunakan sebagai pengertian yang mencakup 
kepercayaan terhadap Tuhan Yang Maha Esa.

Sesuai dengan asas expressio unius exclusio alterius juga telah ternyata bahwa pembentuk undang-undang memaksudkan konsep tentang "agama" dalam Pasal 61 ayat (1) dan ayat (2) serta dalam Pasal 64 ayat (1) dan ayat (5) UU Administrasi Kependudukan hanya dimaksudkan untuk digunakan terhadap satu hal, yaitu dalam hal ini agama"yang diakui sebagai agama sesuai dengan ketentuan Peraturan Perundangundangan", sehingga lagi-lagi dalam hal ini tidak mencakup pengertian kepercayaan terhadap Tuhan Yang Maha Esa.

Kependudukan, in casu Pasal 61 ayat (1) dan ayat (2) serta Pasal 64 ayat (1) dan ayat (5), berpegang pada atau menganut pendirian bahwa "agama" yang dimaksud adalah Agama yang diakui sesuai dengan peraturan perundangundangan.

Dengan kata lain, hak atau kemerdekaan warga negara untuk menganut agama dibatasi pada agama yang diakui sesuai dengan peraturan perundang-undangan.

Konsekuensinya, secara a contrario, tanggung jawab atau kewajiban konstitusional negara untuk menjamin dan melindungi hak atau kemerdekaan warga negara untuk menganut agama, yang sesungguhnya juga termasuk kepercayaan terhadap Tuhan Yang Maha Esa, juga terbatas pada warga negara yang menganut agama yang diakui sesuai dengan ketentuan peraturan perundang-undangan. Hal inilah yang tidak sejalan dengan jiwa UUD 1945 yang secara tegas menjamin bahwa tiap-tiap warga Negara merdeka untuk memeluk agama dan kepercayaan dan untuk beribadah sesuai dengan agama dan kepercayaan itu.

Bahwa adanya pernyataan dalam Pasal 61 ayat (2) dan dalam Pasal 64 ayat (5) UU Administrasi Kependudukan yang menyatakan bahwa bagi penghayat kepercayaan kolom "agama" tidak diisi, tetapi tetap dilayani dan dicatat dalam database Kependudukan, hal itu bukanlah dimaksudkan untuk memberikan perlindungan dan jaminan negara bagi warga negara penganut kepercayaan terhadap Tuhan Yang Maha Esa, melainkan semata-mata penegasan tentang kewajiban negara untuk memberikan pelayanan kepada setiap warga negarasesuai dengan data yang tercantum dalam database kependudukan yang memang merupakan tugas dan kewajiban negara.

Terhadap rumusan Norma dalam Pasal 61 ayat (1) dan ayat (2) serta Pasal 64 ayat (1) dan ayat (5) UU Administrasi Kependudukan berarti Undang-Undang a quo secara implisit mengkonstruksikan hak atau kebebasan menganut agama, yang sesungguhnya juga termasuk kepercayaan terhadap Tuhan Yang Maha Esa, sebagai pemberian negara. Padahal sebaliknya, hak atau kemerdekaan menganut agama (termasuk menganut kepercayaan terhadap Tuhan Yang Maha Esa) adalah hak yang melekat pada setiap orang sebab hak itu diturunkan dari kelompok hak-hak alamiah (natural rights), bukan pemberian negara.Oleh karena hak beragama dan menganut kepercayaan merupakan salah satu hak asasi manusia maka sebagai negara hukum yang mempersyaratkan salah satunyaadanya perlindungan terhadap hak asasi manusia, sehingga membawa konsekuensi adanya tanggung jawab negara untuk menjamin bahwa hak asasi warganya benar-benar ternikmati dalam praktik atau kenyataan sehari-hari.

\section{METODE PENELITIAN}

Data sekunder yang digunakan adalah berbagai peraturan perundangundangan yang terkait dengan penelitian ini, meliputi:

1. Bahan Hukum Primer, diantaranya UUD 1945; UU No 23 Tahun 2006 tentang Administrasi Kependudukan ; UU no 39 Tahun 1999 tentang HAM; Putusan Mahkamah Konstitusi Nomor 
96/PUU-XIV/2016

Pengujian UU Administrasi

Kependudukan.

2. Bahan Hukum Sekunder, meliputi Jurnal Hukum dan Makalah tentang Kepercayaan parmalim.

3. Bahan Hukum Tersier, meliputi Kamus Besar Bahasa Indonesia dan Internet.

Teknik pengumpulan Data, dilakukan dengan dokumentasi observasi, wawancara di lapangan, dan partisipasi lapangan dengan narasumber yang sudah ditentukan peneliti berdasarkan karateristik penelitian.

Teknik pengujian keabsahan Data yakni reduksi data, penyajian data dan penarik kesimpulan dan verifikasi. Aktivitas dalam analisis data kualitatif dilakukan secara interaktif dan berlangsung secara terus menerus sampai tuntas sehingga datanya jenuh.

Teknik yang digunakan adalah triangulasi pada sumber data yakni menguji kredibilitas data dilakukan dengan mengecek data yang diperoleh beberapa sumber misalnya wawancara dengan informan, melakukan perbandingan persepsi pandangan dan pendapat umum dengan persepsi pandangan dan pendapat peneliti dan melakukan perbandingan antara hasil wawancara dengan dokumen dokumen hasil kajian pustakaan.

\section{HASIL DAN PEMBAHASAN}

Efektifitas Pelayanan Hak-Hak Sipil Agama Local Pasca Putusan Mahkamah Konstitusi Nomor 97/Puu-Xiv/2016 Tentang Pengujian Undang-Undang Administrasi Kependudukan Terhadap Kepercayaan Parmalim Di Kota Medan. Kata kepercayaan dalam Pasal 29 ayat 2 mengandung multi inteprestasi berdampak tidak sederhana. Indonesia dikenal sebagai Negara yang mempunyai tingkat pluralism tinggi dalam bidang pemahaman terhadap agama yang dianutnya. Tradisi dan kepercayaan local terjadi karena alkuturasi antara tradisi besar dengan tradisi kecil yang berlangsung lama.Agama dan tradisi local diwariskan dari generasi yang satu ke generasi melalui sosialisasi dan enkulturasi.

Penganut parmalim secara umum telah mengalami stagnasi. Namun tradisi adat mereka dapat dipertahankan oleh para pengikutnya. Kebijakan pemerintah menyangkut pelayanan hak-hak sipilnya belum mencerminkan implemantasi uu no 23 tahun 2006 tentang. Administrasi Kependudukan.Akta kelahiran dan pencatatan nikah sudah dilayani oleh pemerintah meskipun sudah ada dari undang-undang.

Kementerian Agama (Kemenag)

serta Kementerian Pendidikan dan Kebudayaan (Kemendikbud) telah merumuskan sejumlah opsi pengisian kolom agama di KTP elektronik (e-KTP) bagi para penghayat kepercayaan.Opsi pertama adalah dengan menuliskan "penghayat kepercayaan".Kedua dengan menuliskan "kepercayaan kepada Tuhan Yang Maha Esa" alasannya penghayat kepercayaan ditafsirkan sebagai pelakunya bukan keyakinan yang dianut. Ketiga, menuliskan secara spesifik nama-nama aliran kepercayaan yang dianut sesuai dengan nama organisasi mereka. Dari ketiga opsi itu, yang paling berpotensi menimbulkan persoalan adalah apabila kolom agama bagi penghayat kepercayaan ditulis spesifik sesuai nama organisasi. Contoh: Galih Puji Rahayu, Tong Tong Raja Sikalem, Ilmu Roso Sejati, Ilmu Goib, Ilmu Goib Kodrat Alam, dan Golongan Siraja Batak. Banyaknya nama organisasi kepercayaan yang ada di Indonesia, akan menimbulkan persoalan jika ditulis spesifik dalam kolom KTP elektronik. Hal ini karena, sebuah organisasi bisa berubah nama, bisa membubarkan diri, dan bahkan bisa dibubarkan pemerintah.

Kolom agama pada e-KTP warga Baduy yang menganut kepercayaan pun sengaja dikosongkan. Perbaikan data kepercayaan akan dilakukan setelah format penulisan kolom keyakinan dipastikan 
pemerintah. Penggantian ini akan mudah karena datanya sudah terekam semua.

Masyarakat Badui bagian dari Negara Kesatuan Republik Indonesia (NKRI), namun kepercayaan yang dianut rakyatnya tidak diakui dalam kolom eKTP.Semestinya, pemerintah mengakui secara resmi kepercayaan Selam Sunda Wiwitan sebagai agama masyarakat Badui yang merupakan peninggalan nenek moyang itu.

Seorang paguyuban penghayat kapribaden, Hartini Wahyono dengan penganut kapribaden dari Bali, Jawa tengah, Jawa timur, Yogyakarta, Jawa Barat dan Jakarta memiliki penghayat Kapribaden dari dulu pada masa pemerintahan Soeharyo sebagai bagian dari organisasi terlarang Partai Komunis Indonesia. Pada masa dahulu ada Badan Koordinasi Pengawas Aliran Kepercayaan Masyarakat (Bakor Pakem), organisasi di bawah Kejaksaan Agung yang tersebar di setiap provinsi dan kabupaten, yang diatur dalam Undang-Undang 2004 tentang Kejaksaan Republik Indonesia. Tugasnya mengawasi aliran kepercayaan yang dapat membahayakan masyarakat dan negara.

Pertama oleh Kementerian Agama pada 1952 untuk mengawasi aliran kebatinan/kepercayaan.Perannya semakin meluas melibatkan Kementerian Agama, polisi, militer, dan pemerintah daerah dengan menempatkan penghayat kepercayaan sebagai rumah kaca setelah diatur dalam UU Kejaksaan tahun 1961.

30 organisasi keagamaan, dari kepercayaan asli seperti Agama Djawa Sunda (1964) hingga organisasi keagamaan internasional seperti Saksisaksi Yehuwa (1976). Untuk menjadi Penghayat Kapribaden, agama dan kepercayaan lain harus ditanggalkan. Mereka berupaya mengosongkan kolom agama dalam KTP.Kolom agama yang kosong itu memicu diskriminasi. Penghayat kepercayaan di seluruh Indonesia, termasuk Kapribaden yang KTP-nya kosong, mau daftar jadi TNI atau Polri tidak bisa, Mereka pun tak bisa mendafar sebagai pegawai negeri sipil. Sebagai Ketua Presidium Majelis Luhur Kepercayaan Indonesia, Suhartono diundang sebagai pihak terkait oleh Mahkamah Konstitusi.Ia menyambut baik MK yang mengabulkan seluruh permohonan pemohon dalam Putusan MK 97/PUU-XIV/2016. Putusan itu menjadi suplemen kekuatan agar penghayat kepercayaan bisa menghirup iman tanpa kecemasan.

Permasalahan pengisian kolom agama atau kepercayaan bagi penghayat kepercayaan tersebut merupakan suatu bentuk faktor yang sama dirasajan semua penghayat kepercayaan. Makanya banyak masyarakat mendorong masyarakat adat mengajukan konstitusi terhadap Undangundang Administrasi Kependudukan ke MK tahun 2016 yang mempersalahkan Pasal 61 ayat 1 dan ayat 2, Pasal 64 ayat 1 dan 5 terkait pencantuman kolom kepercayaan dalam dokumen kependudukan berupa KTP-el. Judicial review yang diajukan oleh masyarakat adat.

Di Indonesia juga tak ada payung hukum bagi pernikahan antara penghayat dan salah satu dari enam agama resmi yang diakui negara. Jika tetap dipaksakan, Kantor Urusan Agama akan menolak wali yang jadi saksi pernikahan dari pihak penghayat, melimpahkan urusan ke Kantor Catatan Sipil. Tata cara perkawinan anaknya dengan adat Kapribaden berubah dan masuk beragama Islam.

Seseroang yang telah mendapat sertifikasi Direktorat Penghayat Kepercayaan dari Kemendikbud sebagai pemuka penghayat, memikul wewenang untuk mengurus surat pernikahan penghayat kepercayaan. Pernikahan warga Kapribaden hanya bisa dilakukan dengan sesama warga Kapribaden atau penghayat kepercayaan lain. Di luar itu, tidak ada berwenang turut mengurus pernikahan ke Kantor Catatan Sipil.

Pada saat di sekolah juga, Penghayat Kapribaden beribadah dan berdoa jadi merasa terintimidasi karena 
kitab suci mereka tidak ada, maka dengan ada peraturan Menteri Pendidikan Tahun 2016 tentang layanan pendidikan kepercayaan terhadap Tuhan Yang Maha Esa pada satuan pendidikan. Pasal 3 menyebutkan bahwa penyedia pendidikan kepercayaan, pemerintah, pemerintah daerah, dan satuan pendidikan dapat bekerja sama dengan organisasi penghayat kepercayaan, yakni Majelis Luhur Kepercayaan Indonesia.

Di Kota Medan, pembuatan KTP-el memang membawa pengakuan Parmalim banyak mengetahui keberdaan Putusan Mahkamah Konstitusi sebendarnya menjadi dasar pengakuan atas identitas kepercayaan leluhur yang mereka yakini.

$$
\text { Pasca-putusan Mahkamah }
$$

Konstitusi (MK) perkara nomor 97/PPU$\mathrm{XIV} / 2016$, status penghayat kepercayaan dapat dicantumkam dalam kolom agama di kartu keluarga dan kartu tanda penduduk elektronik tanpa perlu merinci aliran kepercayaan yang dianut.

Ada perlakuan yang berbeda bagi masyarakat adat yang masih murni memeluk agama local yang sudah beralih memeluk salah satu agama yang diakui oleh Negara. Bagi masyarakat adat yang sudah beralih memeluk agama yang diakui oleh nengara tidak diperlakukan diskriminatif oleh Negara artinya tidak sulit mendapatkan dokumen kependudukan. Bagi masyarakat adat yang tetap memeluk agama local, yang mendapatkan perlakuan diskriminatif, di KTP tertulis kolom kepercayaan bukan agama yang diputuskan oleh Mahkamah Konstitusi (MK) perkara nomor 97/PPU$\mathrm{XIV} / 2016$.

Setelah putusan MK, pemerintah, khususnya Direktorat Jenderal Kependudukan dan Pencatatan Sipil Kementerian Dalam Negeri, harus segera membuat ketentuan teknis dalam mencantumkan status penghayat kepercayaan di e-KTP.Mengingat ada sejumlah pihak yang mempersoalkan putusan MK tersebut.ketentuan pencantuman status penghayat kepercayaan dari Kemendagri penting untuk diterbitkan sebagai pedoman bagi pemerintah daerah dalam pemenuhan hak sipil. Namun, bahwa prinsip negara harus melayani semua pencatatan sipil bagi seluruh warga negara itu sebuah keharusan.untuk warga negara yang memeluk agama dan telah mempunyai eKTP, tidak dilakukan perubahan atau penggantian e-KTP sama sekali. Pembedaan kartu identitas tersebut justru akan tetap menimbulkan diskriminasi, misalnya dalam hal pencatatan perkawinan.

Dewan Pimpinan Majelis Ulama Indonesia ( MUI) mengusulkan kepada pemerintah agar membuat e-KTP khusus bagi warga penghayat kepercayaan. Di dalam e-KTP tersebut dicantumkan kolom kepercayaan tanpa ada kolom agama. Sementara untuk warga negara yang memeluk agama dan telah mempunyai KTP elektronik, tidak dilakukan perubahan atau penggantian KTP elektronik sama sekali. MUI mengusulkan kepada pemerintah agar kepada penghayat kepercayaan diberikan KTP-elektronik yang mencantumkan kolom kepercayaan tanpa ada kolom agama.

Pembuatan KTP elektronik untuk warga penghayat kepercayaan dengan kolom khusus adalah solusi terbaik dalam melaksanakan putusan MK. Sebab, MUI memandang agama dan kepercayaan merupakan dua hal yang berbeda.

Pembuatan KTP elektronik untuk warga penghayat kepercayaan dengan kolom khusus adalah solusi terbaik bagi bangsa dan negara dalam rangka melaksanakan Putusan MK secara arif dan bijaksana. Adanya perbedaan antara isi KTP elektronik untuk umat beragama dengan penghayat kepercayaan bukanlah diskriminasi, melainkan bentuk perlakuan negara yang disesuaikan dengan ciri khas dan hak warga negara yang berbeda.

Perbedaan antara isi KTP elektronik untuk umat beragama dengan penghayat kepercayaan bukanlah pembedaan yang bersifat diskriminatif atau 
pengistimewaan, namun merupakan bentuk perlakuan negara yang disesuaikan dengan ciri khas dan hak warga negara yang berbeda, Warga penghayat kepercayaan punya hak sebagai warga negara untuk mencantumkan kolom kepercayaan dalam KTP elektroniknya sebagai identitas dirinya,

Seperti halnya kaum Lom, penghayat kepercayaan sebagai suku asli Pulau Bangka.Suku ini diidentifikasi di Dusun Pejem, Dusun Tuing, Dusun Mapur semuanya di Kabupaten Bangka. Lom merujuk pada komoditas dimana orangorang didalamnya belum memeluk suatu agama sehingga sudah memeluk agama berarti bukan Lom.

Implementasi putusan Mahkamah Konstitusi dibutuhkan rekayasa masyarakat secara umum melalui internalisasi nilai-nilai Pancasila sebagai jiwa bangsa. Nilai Ketuhanan, kemanusiaan, persatuan, demokrasi dan keadilan sosial akan memudahkan pelaksanaan putusan mahkamah ini bagi kaum Parmalim dan gejolak gejolak sosial dapat dicegah dan dihindari.

\section{Penghambat Legitimasi Penghayat Kepercayaan Parmalim Dalam Pendirian Rumah Ibadah}

Kepercayaan adalah keyakinan bahwa sesuatu yang dipercayai itu benar atau nyata. Sebuah proses maka kepercayaan kepada Tuhan Yang Maha Esa dapat diartikan sebagai suatu pengakuan terhadap suatu kebenaran ajaran yang dibawa seorang penerima wahyu dari Tuhan Yang Maha Esa.

Agama dalam Pasal 61 ayat 1 dan pasal 64 ayat 1 Undang-undang Administrasi Kependudukan bertentangan dengan UUD NRI 1945 dan tidak mempunyai kekuatan hukum mengikat secara bersyarat sepanjang tidak termasuk kepercayaan.

Agama dalam Pasal 61 ayat (1) dan Pasal 64 ayat (1) Undang-Undang Administrasi Kependudukan tidak mempunyai kekuatan hukum tetap sepanjang tidak dimaknai termasuk kepercayaan. Hal serupa juga berlaku untuk Pasal 61 ayat (2) dan Pasal 64 ayat (5) yang dinilai MK tak memiliki kekuatan hukum mengikat. Putusan itu membuat aliran kepercayaan diakui pemerintah. Sebab selama ini, penghayat aliran kepercayaan tak dapat mengisi kolom agama dalam KTP.Tak hanya itu, penghayat mendapat diskriminasi atas fasilitas yang seharusnya didapat terkait administrasi kependudukan.

Pasal 61 ayat 1 putusan Mahkamah Konstitusi adalah final dan mengikat yang dilakukan berdasarkan pilihan-pilihan rasional dan objektif berdasarkan pengkajian yang sangat luas dan sangat mendalam. Pasal 61 Undang-undang Mahkamah Konstitusi menentukan bahwa putusan berlaku ke depan segala subjek perbuatan hukum dan subjek hukum yang sah sebelum putusan Mahkamah konstitusi tetap dianggap sah setelah adanya rezim baru sesudah berlakunya putusan Mahkamah Konstitusi.

Pertama, aliran kepercayaan, kata dia, tidak dianggap sebagai agama. Melainkan, bagian dari kebudayaan.Ini membuat penghayat aliran kepercayaan tidak mendapat fasilitas yang sebanding dengan penganut agama.Pemenuhan fasilitas tempat ibadah, kebutuhan pemeluknya, dan ritual keagamaannya yang jadi hak mereka.

\section{SIMPULAN}

A Simpulan

1. Efektifitas Pelayanan Hak-Hak Sipil Agama Local Pasca Putusan Mahkamah Konstitusi Nomor 97/Puu-Xiv/2016 Tentang Pengujian Undang-Undang Administrasi Kependudukan Terhadap Kepercayaan Parmalim Di Kota Medan adalah masyarakat mendorong masyarakat adat mengajukan konstitusi terhadap Undang-undang Administrasi Kependudukan ke MK tahun 2016 yang mempersalahkan Pasal 61 
ayat 1 dan ayat 2, Pasal 64 ayat 1 dan 5 terkait pencantuman kolom kepercayaan dalam dokumen kependudukan berupa KTP-el. Judicial review yang diajukan oleh masyarakat adat tadi memang membawa angina segar bagi Parmalim sehingga penncantuman penghayat kepercayaan untuk dihormati dan diakui dalam administrasi kependudukan berupa pencantuman kepercyaan pada KTP-el di Parmali di kota Medan.

2. Penghambat Legitimasi Penghayat Kepercayaan Parmalim Dalam Pendirian Rumah Ibadah dikarenakan minoritas parmalim menganut agama-agama besar yang diakui di Indonesia. Datangnya penghambat dari tidak banyaknya masyarakat paham akan dan menyebut parmalim sebagai sipele begi (penyembah setan). Oleh karena itu pendirian rumah ibadah masih minim karena tidak ada pemerintah kota medan untuk mendirikan rumah ibadah.

B. Saran

1. Sebaiknya dalam dunia adminstrasi pemerintah Kota Medan menyediakan sarana untuk menyelesaikan adminstrasi kaum Parmalim, sebagai mempermudah urusan mengurus $\mathrm{KK}$, KTP dan perkawinan maupun dalam urusan Penerimaan Pegawai Negeri Sipil.

2. Sebaiknya untuk pemerintah Kota Medan, menerapkan Pasal 61 ayat 2 memperbolehkan kepercayaan dalam menganut kolom agama sehingga di sekolah-sekolah ada pendirian rumah ibadah.

\section{DAFTAR PUSTAKA}

\section{A Buku- Buku}

Praja, Juhaya S, 2017, Aliran-aliran Filsafat dan Etika, Prenada Media Group, Jakarta.

Rahnip, Aliran Kepercayaan dan Kebatinan dalam Sorotan, Pustaka Progresif.

Husaini, Adian, Sejarah dan Masalahnya Pasca Putusan Mahkamah konstitusi, Insist.

Subagya, Rahmat, 2019, Kepercayaan, Kebatinan, Kerohaniaan, dan Agama, Kanisius, Cetakan kesepuluh, Jakarta. .

Simorangkir, J. C. T.,1983, Kamus Hukum, Aksara Baru, 1983

\section{B. Peraturan Perundang-undangan}

Undang-undang Nomor 24 Tahun 2003 tentang Mahkamah Konstitusi

Undang-undang Nomor 19 Tahun 2016 tentang Informasi dan Transaksi Elektronik

\section{Internet/ Kamus}

Simbolon, Nanci Yosepin, Pemberdayaan Kearifan Lokal Masyarakat Adat Batak Toba Dalam Mencegah Kekerasan Terhadap Anak, jurnal mercatoria Vol 12 No 2 Tahun 2019 diakses dalam ojs.uma.ac.id/index.php/mercatoria/s earch/authors/view?first name 